\title{
UJI DAYA HAMBAT EKSTRAK KENTAL DAUN KRATOM (Mitragyna speciosa Korth) TERHADAP BAKTERI Staphylococcus aureus SEBAGAI PENYEBAB JERAWAT
}

\section{POWER TEST OF THE CONDESED EXTRACT OF KRATOM LEAVES AGAINST THE GROWTH OF BACTERIAL Staphylococcus aureus AS THE CAUSE OF ACNE}

\author{
Husnani, Suhaimi, Heny Puspasari, Yunita Sari \\ Akademi Farmasi Yarsi Pontianak \\ Jl. Panglima Aim Pontianak
}

Summited : 22Agustus 2019 Reviewed : 04Maret 2020

Accepted : 29Maret 2020

\begin{abstract}
ABSTRAK
Telah dilakukan penelitian dengan judul “ Uji Daya Hambat Ekstrak Kental Daun Kratom ( Mitragyna speciosa Korth) Terhadap Pertumbuhan Bakteri Staphylococus aureus Sebagai Penyebab Jerawat. Penelitian ini bertujuan untuk mengetahui ada tidaknya daya hambat dan pada konsentrasi berapa ekstrak kental daun kratom dapat menghambat pertumbuhan bakteri, ekstrak kental daun kratom terhadap pertumbuhan bakteri Staphylococcus aureus. Pengujian daya hambat dilakukan dengan metode sumuran dengan perlakuan yang berbeda yaitu konsentrasi ekstrak 30\%, 35\%, 40\%, 45\%, 50\%, kontrol positif ( antibiotik tetrasiklin ), dan kontrol negatif ( etanol 96\% ). Hasil pengukuran rata-rata diameter daya hambat yaitu konsentrasi $30 \%$ sebesar $6,67 \mathrm{~mm}, 35 \%$ sebesar 7,31 mm, $40 \%$ sebesar $8,71 \mathrm{~mm}, 45 \%$ sebesar $9,38 \mathrm{~mm}, 50 \%$ sebesar 13,88 mm, kontrol positif sebesar $14,26 \mathrm{~mm}$, dan kontrol negatif sebesar $0 \mathrm{~mm}$. Hasil penelitian menunjukkan bahwa ekstrak etanol daun kratom mempunyai daya hambat terhadap pertumbuhan bakteri Staphylococcus aureus, dan ekstrak daun kratom sudah mampu mengahmbat pertumbuhan bakteri Staphylococcus aureus pada konsentrasi 30\% dengan diameter daya hambat sebesar 6,67 $\mathrm{mm}$.
\end{abstract}

Kata Kunci : Daun Kratom ( Mitragyna speciosa Korth ), Ekstrak, Diameter Daya Hambat, Bakteri Staphylococcus aureus.

\begin{abstract}
The research has been conduted entitled "Test of Resistance Thick Extract of Kratom Leaves ( Mitragyna speciosa Korth) Against the Growth of Staphylococcus aureus As a Cause of acne". This research aims to whether there is inhibition or not and how many concentration thick extract of kratom leaves against the growth of Staphylococcus aureus as a cause of acne. Inhibitory testing was performed by cup plate technique method with different treatment with concentration $30 \%, 35 \%, 40 \%, 45 \%, 50 \%$, positive control ( tetracycline antibiotic ) and negative control ( ethanol $96 \%$ ). The mean meansurement of the inhibitory power diameter $30 \%$ by $6,67 \mathrm{~mm}, 35 \%$ by $7,31 \mathrm{~mm}, 40 \%$ by $8,71 \mathrm{~mm}, 45 \%$ by $9,38 \mathrm{~mm}, 50 \%$ by $13,88 \mathrm{~mm}$, the positive control is $14,26 \mathrm{~mm}$, and negative control of 0
\end{abstract}


$\mathrm{mm}$. The results showed that kratom leaf thick extract had inhibitory effect on growth of Staphylococcus aureus bacteria at concentration $30 \%$ with $6,67 \mathrm{~mm}$ inhibitor diameter.

Keywords : Kratom Leaf (Mitragyna speciosa Korth), Extract, Resistance Diameter, Staphylococcus aureus Bacteria.

\section{Penulis Korespondensi :}

Husnani

Akademi Farmasi Yarsi Pontianak Jl. Panglima Aim No.2 Pontianak

Email :husnani.apoteker@gmail.com

\section{PENDAHULUAN}

Indonesia sebagai negara yang beriklim tropis dan bertambah subur memiliki berbagai jenis tanaman,salah satunya tanaman obat-obatan. Banyak tanaman yang memiliki khasiat sebagai obat,tetapi sebagian besar dari tanaman tersebut tidak dikenali.Tanaman tersebut tumbuh secara liar tanpa dikenali dengan baik sehingga pemanfaatannya belum maksimal. Seiring berjalannya waktu pengetahuan tentang tumbuhan obat makin berkembang,kini tanaman obat telah diketahui manfaatnya.Masyarakat kini lebih cenderung untuk meggunakan obat dari alam (Febriyati,2010).

Kratom merupakan salah satu jenis tumbuhan yang terdapat dalam wilayah hutan Indonesia. Banyak terdapat di daerah Kapuas Hulu,Kalimatan Barat. Kratom merupakan tanaman potensial yang dapat ditingkatkan nilai kegunaannya, karena sejak dahulu kratom sudah dimanfaatkan secara tradisional.

Kratom mempunyai berbagai macam nama di berbagai Negara. Misalnya di Thailand kratom dikenal dengan nama kakuam, ithang atau Thom, sedangkan di Amerika Serikat dikenal dengan nama kratom. Kratom juga dikenal sebagai ketum dan biak. Masyarakat Dabra (Mamberamo) Papua mengenal kratom sebagai bika (Seirots, 2009).

Kratom merupakan salah satu tanaman obat tradisional yang menghasilkan efek stimulan (pada dosis rendah), efek antiinflamasi dan efek sedatif (pada dosis tinggi), diare, melancarkan peredaran darah, peningkatan daya tahan tubuh dan stamina, mencegah sembelit, mengobati diabetes dan menurunkan kadar gula diabetes. Tanaman kratom memilikikandungan yaitu alkaloid, flanonoid, fenol, terpenoid -steroid,triterpenoid, saponin, dan tanin (Febrianti riska, 2016).

Jerawatadalah peradanganyang disertai denganpenyumbatansaluran kelenjarminyakkulitdan rambut (saluran (pilosebasea).Apabilasaluran pilosebasea tersumbat,makaminyak kulit(sebum) tidakdapatkeluardan mengumpul didalamsaluran, saluran menjadimembengkak sehingga terjadi komedo. Komedo merupakan permulaan terbentuknyajerawat,baik komedoterbuka (blackhead)atau komedotertutup (whitehead) (Tranggono,dkk.,2007).Biasanya disebabkanolehbakteriStaphylococcus aureus.

Jerawat bisa disebabkan oleh beberapa faktor Internal yaitu keturunan,pubertas,alergi,pola hidup yang kurang bersih, wajah berminyak,dan jiwa(banyakfikiran), danfaktor eksternal yaitu makanan,dan minuman,iklim dan polusi udara, penggunaan kosmetik yang berlebihan.

Bakteri Staphylococcus aureus merupakan bakteri penyebab jerawat, termauk bakteri gram positif dengan sedikit lipid.Bakteri ini tumbuh pada suhu optimum $37^{\circ} \mathrm{C}$, tetapi membentuk pigmen paling baik pada suhu kamar $\left(20-25^{\circ} \mathrm{C}\right)$.

Klasifikasi S. aureus adalahsebagai berikut :

$\begin{array}{ll}\text { Kingdom } & \text { : Procaryota } \\ \text { Divisi } & \text { : Firmicutes } \\ \text { Class } & \text { : Bacilli } \\ \text { Ordo } & : \text { Bacillales } \\ \text { Family } & : \text { Staphylococcaceae }\end{array}$




\author{
Genus : Staphylococcus \\ Species : :Staphylococcus aureus
}

Antibiotik adalah zat yang dibentuk oleh mikroorganisme yang dapat menghambat atau membunuh pertumbuhan mikroorganisme lain. Zat yang bersifat antibiotik dapat pula dibentuk oleh beberapa tumbuhan atau hewan tingkat tinggi, disamping itu berdasarkan antibiotik alam dapat pula disebut antibiotik baru secara sintesis yang sebagian mempunyai sifat yang lebih baik. Tetrasiklin adalah sekelompok obat yang memiliki karakteristik fisik dan famakologis yang berbeda, tetapi memiliki sifat antimikroba yang nyaris identik dan anggota-anggotanya memiliki resistensi-silang sempurna. Tetrasikilin dikonsentrasikan oleh bakteri yang sensitive, kemudian menghambat sintesis protein dengan menghambat pengikatan aminoasil-tRNA ke unit 30S ribosom bakteri. Obat ini menghambat bakteri gram positif dan gram negatif yang peka atau yang sensitive (dihambat pada konsentrasi 0,1-10 g/ml). Dosis rendah tetrasiklin selama berbulan-bulan diberikan untuk terapi "acne" untuk menekan bakteri kulit dan lipasenya, yang menimbulkan perubahan-perubahan peradangan (Jawetz, 1980).

\title{
METODE PENELITIAN \\ Alat dan Bahan
}

Alat yang digunakan dalam penelitian ini adalah autoklaf(YX280D), batang pengaduk, bejana maserasi, cawan petri, corong kaca, erlenmeyer(Pyrex), gelas ukur (Pyrex), gelas beaker(Pyrex), hot plate(Maspion), inkubator(Memert), jangka sorong(Tricle brand), jarum ose, mikropipet(Brand), neraca analitik(Lucky), oven(Gemmyco), pinset, pipit tetes, pisau stainless, tabung reaksi, dan rotary evaporator.

Bahan - bahan yang digunakan dalam penelitian ini adalah daun kratom (Mitragyma specioca Korth), aquadest, antibiotik tetrasiklin sebagai kontrol positif,etanol $96 \%$ sebagai kontrol negatif, aluminium foil,cakram disc, kapas, kain kasa, NaCL 0,9\%, kultur murni Staphylococcus aureus, Nutrien Agar (NA), medium Mueller Hinton Agar (MHA)spirtus.

\section{Prosedur Kerja}

Pembuatan Konsentrasi Ekstrak Daun KratomKonsentrasi ekstrak daun kratom 30 $\%, 35 \%, 40 \%, 45 \%$, dan $50 \%$ b/v dibuat dengan cara menimbang ekstrak daun kratom sebanyak $3 \mathrm{~g}$; 3,5 g; $4 \mathrm{~g} ; 4,5 \mathrm{~g}$; dan 5 g masing-masing dimasukkan dalam labu ukur yang telah berisi etanol $96 \%$ hingga $10 \mathrm{ml}$ dan kocok hingga larut, dan selanjutnya siap untuk dilakukan penelitian.

Pembuatan Larutan Kontrol Positifdibuat larutan tetrasiklin dengan cara membuka cangkang kapsul kemudian dilarutkan dalam $10 \mathrm{ml}$ aquadest $\mathrm{d}$ dalam vial lalu ditutup dengan menggunakan alumunium foil.

Pembuatan Larutan Kontrol Negatifdisiapkan $10 \mathrm{ml}$ etanol 96\% dan dimasukkan kedalam vial,lalu ditutup dengan menggunakan alumunium foil.

Peremajaan bakteri ujidengan carakultur murni bakteri Staphylococcus aureus, diinokulasikan sebanyak 1 ose pada medium NA miring dalam tabung reaksi dengan cara digoreskan secara zig-zag dan aseptis, kemudian diinkubasi selama 48 jam pada suhu $37^{\circ} \mathrm{C}$.

Pembuatan suspensi bakteri uji Bakteri uji hasil peremajaan disuspensikan dengan larutan $\mathrm{NaCl}$ 0,9\% dengan cara diambil 1 ose bakteri yang telah diremajakan dan dimasukkan kedalam tabung reaksi yang berisi $10 \mathrm{ml}$ larutan $\mathrm{NaCl} 0,9 \%$.

Pengujian daya hambat ekstrak daun kratom dilakukan dengan metode sumuran. Dimasukkan $1 \mathrm{ml}$ suspensi bakteri kedalam cawan petri, kemudian digoyangkan cawan petri agar suspensi bakteri homogen. Disiapkan medium MHA steril yang telah dipanaskan dan didinginkan, kemudian secara aseptis dimasukkan kedalam cawan petri steril didiamkan hingga padat, kemudian pada media tersebut dibuat sumuran menggunakan pipet tetes lalu dimasukkan $0,5 \mathrm{ml}$ konsentrasi ekstrak dan larutan kontrol positif dan negatif, diinkubasi pada suhu $37^{\circ} \mathrm{C}$ selama 24 jam dengan posisi terbalik. 


\section{Analisis Data}

Penentuan daya hambat pertumbuhan bakteri uji dilakukan dengan mengukur luas daerah zona bening sekitar kertas saring. Pengamatan dilakukan setelah diinkubasi selama 48 jam dengan menggunakan jangka sorong.

\section{HASIL DAN PEMBAHASAN}

Pengujian daya hambat menggunakan metode sumuran dengan ukuran lubang $7 \mathrm{~mm}$, parameter yang diamati adalah dengan adanya diameter daya hambat atau zona bening disekitar lubang sumuran masing - masing konsentrasi. Metode sumuran memiliki kelebihan yaitu mudah mengukur luas zona hambat yang terbentuk karena isolate beraktivitas tidak hanya dipermukaan atas Mueller Hinton Agar tetapi juga sampai ke bawah.

Setelah diinkubasi selama 48 jam menunjukkan hasil diameter zona bening yang dapat diartikan bahwa ekstrak kental daun kratom bersifat (menghambat) karena terlihat jelas zona bening tiap masing - masing konsentrasi dan juga dapat dilihat dari tabel hasil diatas menunjukkan bahwa semakin besar konsentrasi ekstrak daun kratom yang digunakan maka semakin besar pula diameter daya hambat terhadap bakteri Staphylococcus aureus.

Parameter yang diamati pada penelitian ini adalah ditunjukkan dengan adanya diameter daya hambat atau zona bening disekitar sumuran yang berdiameter $7 \mathrm{~mm}$ pada masing-masing konsentrasi. Hasil pengukuran diameter daya hambat ekstrak kental daun kratom (Mitragyna speciosa korth) terhadap bakteri Staphylococcus aureus dapat dilihat pada tabel dibawah.

Tabel I. Diameter Hambatan Ekstrak Etanol Daun Kratom (Mitragyna speciosa Korth) terhadap Pertumbuhan Bakteri Staphylococcus aureus

\begin{tabular}{|c|c|c|c|c|c|c|}
\hline Perlakuan & $\begin{array}{c}\text { Replikasi } \\
1\end{array}$ & $\begin{array}{c}\text { Replikasi } \\
2\end{array}$ & $\begin{array}{c}\text { Replikasi } \\
\mathbf{3}\end{array}$ & $\underset{(\mathrm{mm})}{\text { Jumlah }}$ & $\begin{array}{l}\text { Rata- } \\
\text { Rata } \\
(\mathrm{mm})\end{array}$ & SD \\
\hline Ekstrak daun kratom $30 \%$ & 6,12 & 7,25 & 6,65 & 20,02 & 6,67 & 0,56 \\
\hline Ekstrak daun kratom35\% & 7,55 & 6,82 & 7,57 & 21,94 & 7,31 & 0,42 \\
\hline Ekstrak daun kratom $40 \%$ & 8,02 & 8,22 & 9,9 & 26,14 & 8,71 & 1,03 \\
\hline Ekstrak daun kratom $45 \%$ & 8,67 & 8,37 & 11,1 & 28,14 & 9,38 & 1,49 \\
\hline Ekstrak daun kratom 50\% & 14,67 & 14,12 & 12,85 & 41,64 & 13,88 & 0,93 \\
\hline Kontrol + (Tetrasiklin) & 18,5 & 18.62 & 19,95 & 57,07 & 14,26 & 0.80 \\
\hline Kontrol - (etanol 96\%) & - & - & - & - & - & - \\
\hline
\end{tabular}

Berdasarkan tabel I dapat diketahui ekstrak kental daun kratom pada konsentrasi terkecil yaitu 30\% sudah dapat menghambat pertumbuhan bakteri Staphylococcus aureus dengan rata - rata diameter daya hambat $6,67 \mathrm{~mm}$, dan pada konsentrasi terbesar yaitu $50 \%$ sebesar 13, $88 \mathrm{~mm}$. Sedangkan diameter daya hambat kontrol positif sebesar 18,5 mm, dan untuk kontrol negatif tidak menunjukkan pertumbuhan bakteri.

Nilai standar deviasi menggambarkan seberapa jauh variasi penyebaran data pada sampel, berdasarkan hasil uji standar deviasi pada tabel 4.1 untuk bakteri Staphylococcus aureus terlihat bahwa setiap konsentrasi memiliki variasi penyebaran data yang sempurna, karena pada setiap konsentrasi nilai standar deviasi yang diperoleh kurang dari 1,5. 


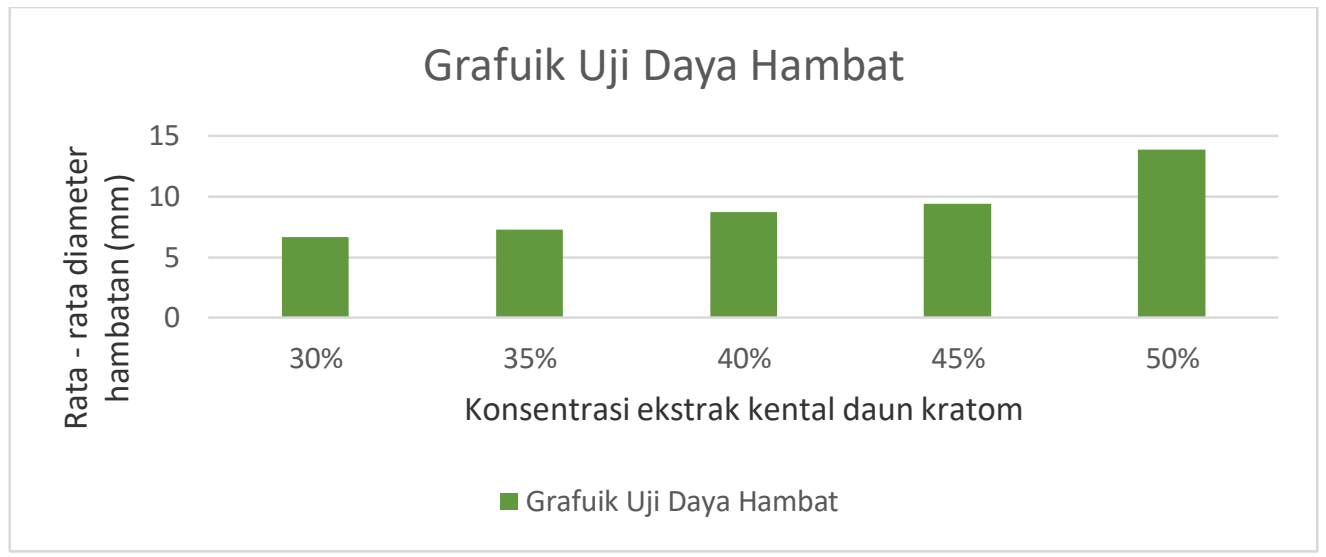

Gambar 1 Grafik Hasil Uji Daya Hambat Ekstrak Kental Daun Kratom Terhadap Pertumbuhan Bakteri Staphylocuccus aureus

Tabel II. Kekuatan Antibakteri

\begin{tabular}{|c|c|}
\hline Diameter zona bening & Kekuatan Antibakteri \\
\hline$>20 \mathrm{~mm}$ & Sangat Kuat \\
\hline $10-20 \mathrm{~mm}$ & Kuat \\
\hline $5-10 \mathrm{~mm}$ & Sedang \\
\hline$<5 \mathrm{~mm}$ & Lemah \\
\hline
\end{tabular}

Sumber : ( Davis stout dalam Ambarwati, 2007)

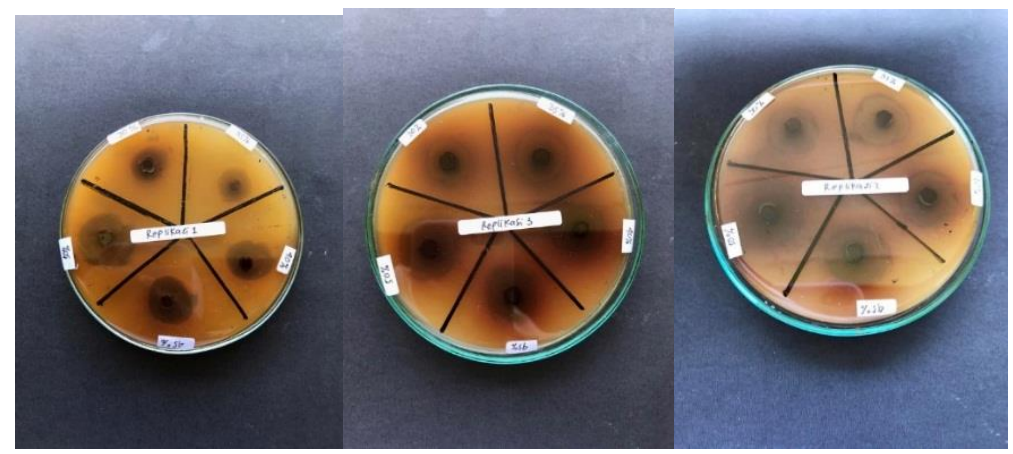
Gambar 2. Hasil Uji Daya Hambat Ekstrak Kental Daun Kratom (Mitragynaspecioca Korth) Terhadap Pertumbuhan Bakteri Staphylococcus aureus

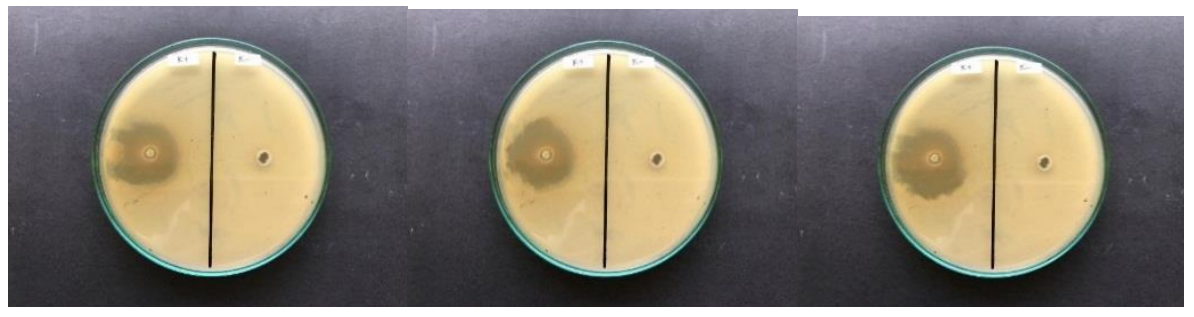

Gambar 3. Hasil Uji Daya Hambat Ekstrak Kental Daun Kratom (Mitragynaspecioca Korth) Terhadap Pertumbuhan Bakteri Staphylococcus aureus Pada Kontrol Positif dan Kontrol Negatif. 


\section{KESIMPULAN}

Berdasarkan penelitian ini dapat disimpulkan bahwa ekstrak kental daun kratom mempunyai diameter daya hambat terhadap pertumbuhan bakteri Staphylococcus aureus sebagai penyebab jerawat pada konsentrasi $30 \%$ dengan diameter daya hambat sebesar 6,67 $\mathrm{mm}$.

\section{UCAPAN TERIMAKASIH}

Ucapan terima kasih peneliti kepada dosen pembimbing serta dana penelitian internal Akademi Farmasi Yarsi Pontianak Tahun 2018 serta teman-teman anggota penelitian internal.

\section{DAFTAR PUSTAKA}

Ambarwati. 2007. Efektivitas ZatAntibakteri Biji Mimba ( Azadirachta Indica) untukMenghambat Pertumbuhan Salmonella thyposa dan Staphylococcus aureus. Jurnal

Biodervisitas. Surakarta : Prodi Kesehatan Masyarakat, Fakultas Ilmu Kesehatan, Universitas Muhammadiyah Surakarta.

Febrianti, Riska. 2016. Penetapan Parameter Standar Simplisia dan Ekstrak Etanol Daun Kratom (Mitragyna Spesioca Korth) Terhadap Yang Tumbuh Di Kabupaten Kapuas Hulu dan Kabupaten Melawi. Karya Tulis Ilmiah. Pontianak, Akademi Farmasi Yarsi Pontianak.

Febriyati, 2010. Analisis Komponen Kimia Fraksi Minyak Atsiri Daun Sirih (Piper bettla Linn) dan Uji Aktivitas Antibakteri Terhadap Beberapa Jenis Bakteri Gram Positif. Skripsi.

Jawetz, E, Melnick, J.L and Alberg, E.A (1980). Review of Medical Microbiology, 14 th edition. Lange Medical Publication. Los Altos. Terjemahan Dr.Gerard Bonang. Penerbit Fakultas Kedokteran Universitas Katolik Indonesia Atmajaya. Jakarta.

Seirots. 2009. Mitragyna speciosa Kratom Botany.

Tranggono, Retno Iswari dan F.Latifah. 2007. Buku Pegangan Ilmu Pengetahuan Kosmetik. PT Gramedia Pustaka: Jakarta 